\title{
How Web Shops Impact Consumer Behavior?
}

\author{
Helena Štimac, Ivan Kelić, Karla Bilandžić
}

\begin{abstract}
The behavior of e-customers is quite unpredictable, which raises additional questions about this topic. The purpose of the paper is to conduct research on e-customers, understand the impact of marketing actions on e-customer behavior and understand the unpredictability of e-customers. Research was conducted on the Mlinar web shop that sells cakes. 284 respondents/buyers had the opportunity to solve questionnaires about behavior after purchase and consumption of product. Different methods have been used in the analysis - descriptive statistics, multivariate analysis (reliability analysis, correlation analysis and linear regression) and analysis of variance (ANOVA). The results showed that most examinees were satisfied with online shopping on the Mlinar web shop and that they are impulsive when online shopping. Saving time is the main reason to buy on a web shop. Research proved that variables such as firm reputation/perceived value, e-satisfaction and online services positively affect the creation of e-loyalty in their users.
\end{abstract}

Keywords: customer behavior; e-customer; marketing; purchasing habits; web shop

\section{INTRODUCTION}

With a rapid development of technology and application in all spheres of business, there is a growing stress being put on consumer behavior in an online environment. Contemporary consumers, in the majority of cases, use the information available on various internet destinations when shopping for a product (pre-shopping, shopping, and postshopping phase), like applications, social profiles, reviews, blogs, vlogs, website information etc. The usage of the aforementioned technologies for economic purposes has become the primary matter in the everyday life of the majority of business subjects, independent of the industry they are in. The majority of business subjects is turning to selling their products online, because buyers, after doing research online, arrive at the virtual store (web shop) in order to conclude their purchase. E-trade and digital markets brought about fundamental changes and movements in all forms of trade. E-trade primarily consists of distribution, transferring information, purchase, sales, marketing, and servicing products and services using the internet or some other electronic systems. Business subjects today strive for the digitalization of their products and services in order not to fall behind the competition in the market, in order to be able to do business globally and come closer to consumers, be available 24/7. Shopping in virtual stores (web shops) developed a stiff competition and the advanced usage of technological innovation with the aim of keeping existing buyers and getting new ones. If we observe the aforementioned activities from a marketing standpoint, web shops enable direct communication with consumers, easier and faster responses to inquiries and comments of users and connecting after purchase through other platforms. It is because of this reason that it is necessary to ask the question just how much of an influence do web shops have on the end consumer i.e. what are the attitudes of a consumer towards this type of shopping.

The aim of this paper is to research the preferences of the consumer on the web shop of the business subject Mlinar. Mlinar, in its portfolio, has a wide array of products, but has specialized for a certain group of products on its web shop. In order to narrow down this research, the authors chose the aforementioned business subject because it only sells torts and pastries on its web shop. That way, only the consumers who purchase the aforementioned group of products were targeted. Based on the primary research, the aim is to explore the trust of consumers towards e-trade, how often they visit certain web shops, and how they perceive the marketing activities of specific business subjects i.e., a specific industry. Given that the majority of business subjects is beginning to offer an e-trade service, the traditional way of buying is changing, and consumers have more of a choice, more flexibility in the place, time, and way of shopping. Precisely because of this, online consumers are different than the traditional ones by their approach to shopping, as well as their reactions to marketing activities, which is the aim of research of this paper.

Considering the aforementioned, this paper sets three hypotheses, in the following order:

H1 - Firm reputation and perceived value have a positive impact on e-loyalty

$\mathrm{H} 2$ - E-satisfaction has a positive impact on e-loyalty

H3 - Online services have a positive impact on e-loyalty

\section{CONSUMER BEHAVIOR IN ONLINE SHOPPING - PRELIMINARIES AND RELATED WORKS}

Consumer behavior is not just about the action and the result of the purchase, but much more than that. For that reason, it can not only be perceived, but must also be studied, in order to reach (and understand) those activities that take place in the mind of the consumer during the purchase process. Therefore, it is not only about marketing, but also about economics and behavioral science in general. According to [1] the term consumer behavior can be defined as behavior that involves "all activities associated with the purchase, use and disposal of goods and services, including the consumer's emotional, mental and behavioral responses that precede or follow these activities." [2] Explained consumer behavior "as the study of individuals, groups, process and organizations they use to secure, select, and arrange of experience, products, services, experiences, or ideas to satisfy the consumer and society". That area of marketing has been researched dynamically and curiously 
since the 1950s and 1960s [3] and, since then, the definition of consumer behavior has remained the same, but everything else is changing - from shopping habits to products and technology.

Alluding to technology, the World Wide Web, invented by Berners-Lee, was developed in 1990, and since then, the mass consumption of the Internet has begun [4]. As the popularity and use of the Internet grows, new technologies are emerging, and one of them are web shops. Furthermore, the development of web shops has influenced the change in customer behavior [5] because those (web shops) are so prevalent nowadays that it is impossible to observe consumer behavior without considering a way of shopping in which physical presence is not required at all. However, with the development of Internet technology, online marketing is also evolving, which brings major changes in marketing practices and changes some of the basic principles of marketing [6]. In addition, the behavior of e-customers is quite unpredictable [7], which raises additional questions about this topic. There is a lot of research on the topic of online shopping [8-11], but [12] states that, until 2002 , only $9 \%$ of the papers include ecustomers topics.

Before discussing the behavior of online consumers in shopping, it is a good idea to mention a study that examined what influences the intention for online shopping. Research [13] has shown that intent is influenced by usefulness, ease of use and enjoyment. Usefulness can be explained as the individual's perception that using the new technology will enhance or improve performance $[14,15]$. Ease of use is defined as the individual's perception that using the new technology will be free of effort. Enjoyment is explained as intrinsic motivation. Furthermore, [16] in their paper, present a model in which consumers' attitudes to e-commerce is influenced by convenience, website design, security, and time saving. And what do e-consumers want from web shops? According to [17], e-consumers "seek for clear information about product and service. Time saving, connivance, wide variety and better price on time are all important factor for online shopping".

In their research about consumer behavior in online shopping, [18] concluded that there is a strong bond between consumer behavior and online selling of products and their marketing strategies. [19] have identified several factors that influence e-shopper behavior, and the same factors have been used to build a research model of this paper. The factors that have an effect on online consumer behavior mentioned by these authors are: e-satisfaction, trust and online risk, eloyalty, online services, perceived value, firm reputation, privacy and functionality. A study conducted among students by [6] showed that some of these factors have more and some less impact on this target group. Therefore, those factors which influence the behavior of online customers more are functionality, privacy, firm reputation, perceived value and trust. In order to build the model for this research, the parameters used are: perceived value and firm reputation (relates to the perceived value that the consumer expects from the purchase and the process itself, and the trust in the brand, its reputation), e-satisfaction (refers to the satisfaction of the customer in terms of satisfying the needs, feel of respect and the cost/price of the product [20], online services (related to the professionalism of the service, consumers should be aware of it, notice it and feel it) and e-loyalty. Eloyalty, as well as loyalty in physical shopping, refers to the link between the brand and the consumer, which causes the consumer to repeat the purchase with the same brand because of a good previous experience with the service, products or the whole process $[6,21]$.

[22], on the other hand, show other factors that influence online consumer behavior. They mention the relationship among demoFigureics, personal characteristics, and attitudes towards online shopping. Also, they mentioned that those who have a "wired" lifestyle are more willing to shop online. The same is true for those who are more limited over time. This is certainly true, but the question is how many more people today have that kind of lifestyle. Many more! This is one of the reasons why e-commerce is developing at a high speed. According to [24] "they suggested that customized information should be provided to the online shoppers who buy standard or repeat items, which can lead to shoppers gaining a feeling of increased convenience, and which in turn will allow them to make quick purchase decisions."

As in the offline shopping form, online shopping also has different types of consumer personality that affect the purchase itself. "Some online consumers are an adventurous explorer, fun seeker, shopping lover, and some are technology muddler, hate waiting for the product to ship" [25]. To better understand the behavior of e-consumers, [23] come to interesting conclusions and facts about the behavior of e-consumers:

- Online shopping is getting popular among the young generation as they feel it is more comfortable, time saving and convenient,

- Customers compare prices from different brands more and more in online shopping than in physical shopping,

- Security has been recognized as a major barrier to online shopping,

- Online shopping is an emerging trend among the 18-33 age group

- Most online shoppers are employed

- Online shoppers are more motivated to buy online as payment is easier (and it is time-saving)

- Online shopping helps when comparing products from different online shopping websites.

\section{RESEARCH METHODS}

E-consumer behavior was observed with the Mlinar web shop. Mlinar is the largest bakery industry in the region, with headquarters in Croatia. It has a network of over 200 stores, which makes this brand nationally recognizable. As such, Mlinar's web shop is the only one in Croatia to own a national web shop for cakes and small cakes. The web shop started its operation in June 2019 and, thanks to strong marketing efforts, it is now recognized nationwide.

\subsection{Sample and Research Design}

Research was done in the period from November $1^{\text {st }} 2019$ to February $1^{\text {st }} 2020$ on a sample of 284 examinees who visited the Mlinar web shop and bought something there. The research i.e. preparing the questionnaire, as well as its 
processing, was done in accordance with the several aims set previously:

- Identifying characteristics and preferences of Mlinar's online shoppers

- Identifying the perceived value of Mlinar's reputation with online shopping

- The satisfaction with buying on Mlinar's web shop

- The satisfaction with services on Mlinar's web shop

- The intent/recommendation of future shopping on Mlinar's web shop with the aim of creating loyalty.

The examinees were familiarized with the aim of research. The first part of the questionnaire was about examining the purchasing habits of examinees. The second part of the questionnaire was based on the satisfaction with shopping, and the third one was created so that there would be answers to the questions related to the intentions of shopping by the examinees so far and in the future. The last part of the questionnaire was about the socio-demoFigureic characteristics of the examinees. Research was conducted by using a highly structured questionnaire. Majority of the questions were closed, using a five-point Likert scale, where 1 indicated the lowest and 5 the highest level of satisfaction.

Detailed sample description is given in Tab. 1.

\begin{tabular}{|c|c|c|c|}
\hline \multicolumn{4}{|c}{ Table 1 Sample description } \\
\hline & & $\mathrm{N}$ & $\%$ \\
\hline \multirow{4}{*}{ Years of age* } & $20-30$ & 21 & 7,4 \\
\cline { 2 - 4 } & $31-40$ & 118 & 41,5 \\
\cline { 2 - 4 } & $41-50$ & 68 & 23,9 \\
\cline { 2 - 4 } & Over 51 & 72 & 25,4 \\
\hline \multirow{4}{*}{ Gender** } & Woman & 240 & 84,5 \\
\cline { 2 - 4 } & Men & 42 & 14,8 \\
\hline \multirow{4}{*}{ Employment status*** } & Unemployed & 22 & 7,7 \\
\cline { 2 - 4 } & Employed & 237 & 83,5 \\
\cline { 2 - 4 } & Student & 16 & 5,6 \\
\cline { 2 - 4 } & Retired & 7 & 2,5 \\
\hline \multirow{4}{*}{ Level of education**** } & High school & 92 & 32,4 \\
\cline { 2 - 4 } & Baccalaureus & 53 & 18,7 \\
\cline { 2 - 4 } & Magister & 104 & 36,6 \\
\cline { 2 - 4 } & Magister of science & 23 & 8,1 \\
\cline { 2 - 4 } & PhD & 8 & 2,8 \\
\hline \multirow{4}{*}{$\begin{array}{c}\text { Monthly household } \\
\text { income***** }\end{array}$} & $<400 €$ & 8 & 2,8 \\
\cline { 2 - 4 } & $401-800 €$ & 28 & 9,9 \\
\cline { 2 - 4 } & $801-1200 €$ & 75 & 26,4 \\
\cline { 2 - 4 } & $1201-1600 €$ & 58 & 20,4 \\
\cline { 2 - 4 } & $>1601 €$ & 95 & 33,5 \\
\hline
\end{tabular}

*Missing $5(1,8 \%)$, ** Missing $2(0,7 \%)$, *** Missing $2(0,7 \%)$, **** Missing $4(1,4 \%), * * * * *$ Missing $20(7 \%)$

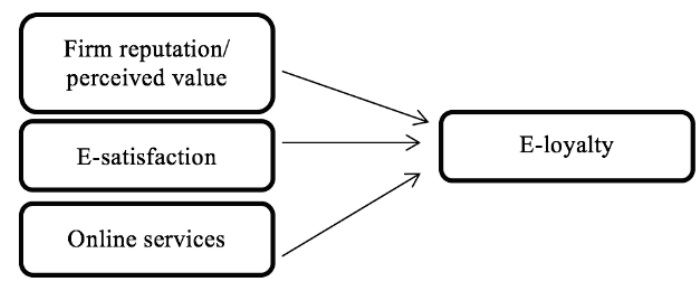

Figure 1 Conceptual model

As was previously stated in the paper, the authors created a model where they want to show how the independent variables (firm reputation/perceived value, e-satisfaction and online services) affect the dependent one (e-loyalty - Fig. 1). The authors adopted measurement scales from [26] for the firm reputation/perceived value, e-satisfaction and online services and from [27] for the e-loyalty value.

The research results were obtained using the statistical package SPSS 23.0. Descriptive statistics, multivariate analysis (reliability analysis, correlation analysis and linear regression), and analysis of variance (ANOVA) were used for data analysis.

\subsection{Research Results}

The first part of research was about examining the habits of shopping i.e. whether the examinees rather shopped in Mlinar stores or the web shop. The results showed that 75,4\% of examinees tried torts/cakes by Mlinar prior to their first online purchase, while $61,6 \%$ of examinees bought a tort/cake earlier in one of Mlinar's stores. The majority of examinees $(72,5 \%)$ first bought a tort/cake by Mlinar on the web shop. The other part of examinees (27,5\%) shopped for torts/cakes on Mlinar's web shop prior to that $(1 \times 4,7 \%, 2 \times$ $13,7 \%, 3 \times 4,6 \%, 4$ and more times $4,5 \%$ ). A very good piece of information for Mlinar is the fact that $63 \%$ of examinees agree they would decide to shop for Mlinar's torts/cakes even if they didn't have a web shop, which proves their recognizability and the quality of their products and services.

When identifying the intent to buy on a web shop, the results showed that $40,5 \%$ of examinees, prior to arriving at Mlinar's web shop already knew what they will buy and did so. An interesting piece of information is that $39,4 \%$ of examinees did not know which article they will buy prior to arriving at Mlinar's web shop, but they bought something anyway. $6,7 \%$ of examinees knew what they wanted to buy before arriving at the web shop, but they ended up deciding for another article, and 13,4\% of examinees bought another article, along with their planned one.

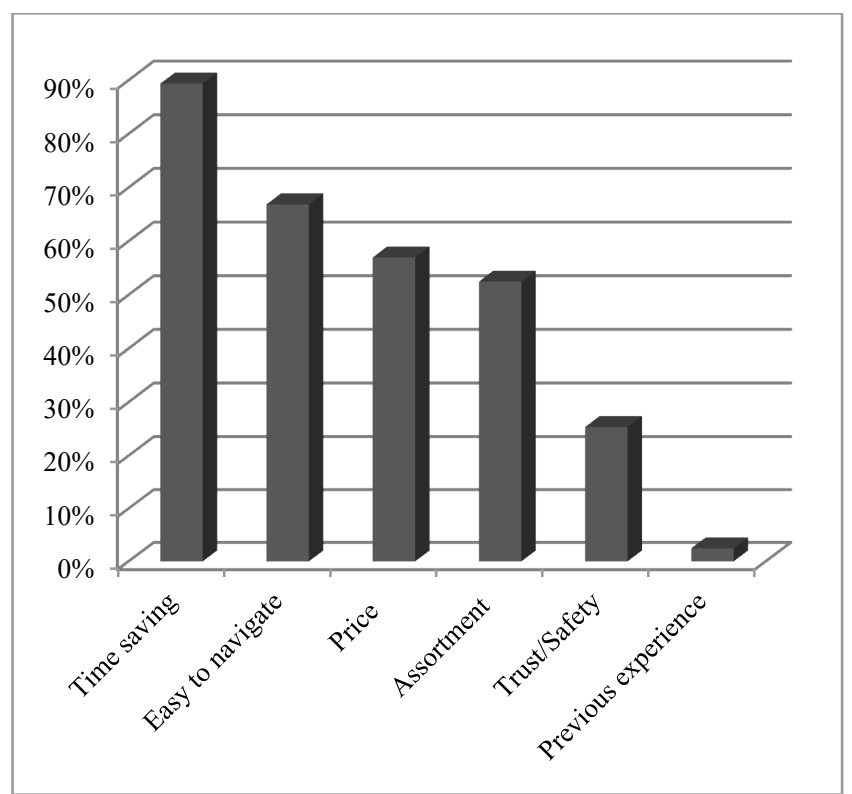

Figure 2 Reasons to buy on Mlinar web shop 
The Fig. 2 shows which are the most frequent reasons of buying on Mlinar's web shop. As can be seen, saving time is the biggest reason for buying on a web shop $(89,4 \%$ of examinees). Apart from the reasons shown on the figure, the remaining reasons are sales, not knowing about other web shops, recommendations, and getting the tort from the "neighborhood" Mlinar store. The majority of examinees $(58,6 \%)$ stated that the cause of ordering torts/cakes were birthdays, and less than $10 \%$ said that it was anniversaries, holidays, parties etc.

Furthermore, results showed that $38 \%$ of exam Mlinar's web shop on Mlinar's website, then using Facebook (30,3\%), and via recommendation by a friend or a family member $(19,7 \%)$. The most frequent channels using which they arrived at Mlinar's web shop are the direct input into the search engine $(50,7 \%)$ and using Mlinar's website $(30,6 \%)$. Social networks, as a channel using which examinees arrived at the web shop, were represented, but not to the extent as the previously stated channels $(11,6 \%$ using Facebook posts or ads, 3,9\% using Instagram posts or ads).

As was stated earlier in the paper, a conceptual model was set using which it was attempted to find out the influence of certain variables on the dependent variable. Therefore, the research wanted to examine the way in which firm reputation/perceived value, e-satisfaction and online services affect e-loyalty (Fig. 1).

Prior to doing a correlation analysis and regression, a descriptive analysis will show the mean values of certain variables within a determined construct. Fig. 3 shows that the attitudes of examinees are positive for the firm reputation/perceived value i.e. the majority of examinees completely agrees that online shopping on Mlinar's web shops makes them happy $(65,1 \%)$, consider that the shop is customer-oriented $(59,2 \%)$, and that they partially or completely agree that they will look to them first when buying torts/cakes online $(49,6 \%)$.

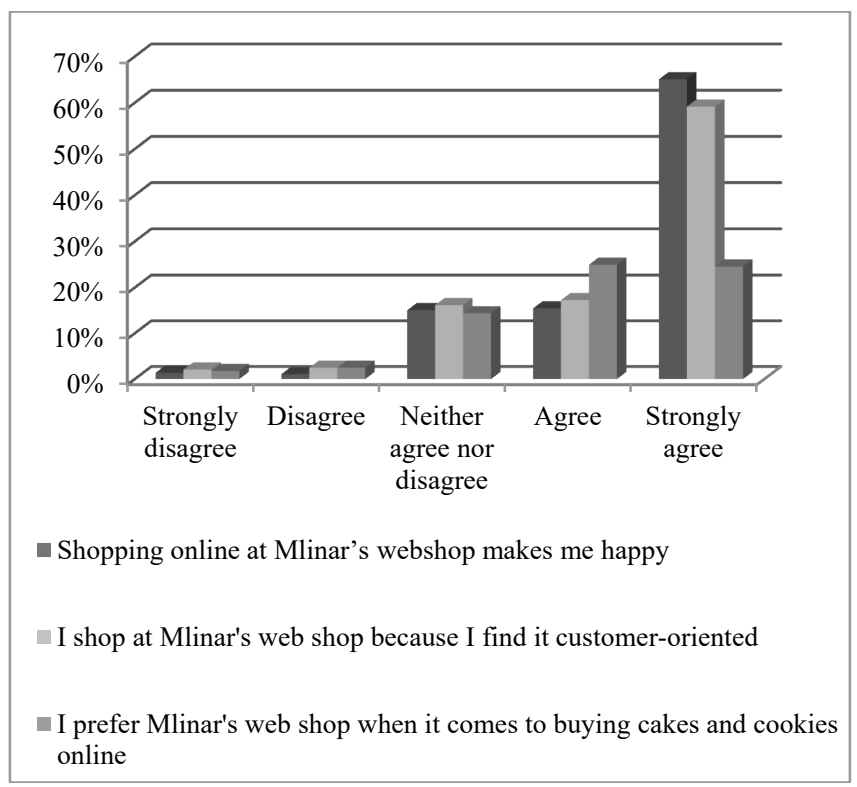

Figure 3 Attitudes of examinees on the firm reputation/perceived value
When the attitudes of examinees on e-satisfaction are observed, the results show that examinees are satisfied with all the variables observed i.e. they are completely satisfied with the prices $(52,8 \%)$, with their expectations $(66,9 \%)$, with the price/quality ratio $(58,1 \%)$, and the range of products $(48,6 \%)$ (Fig. 4$)$.

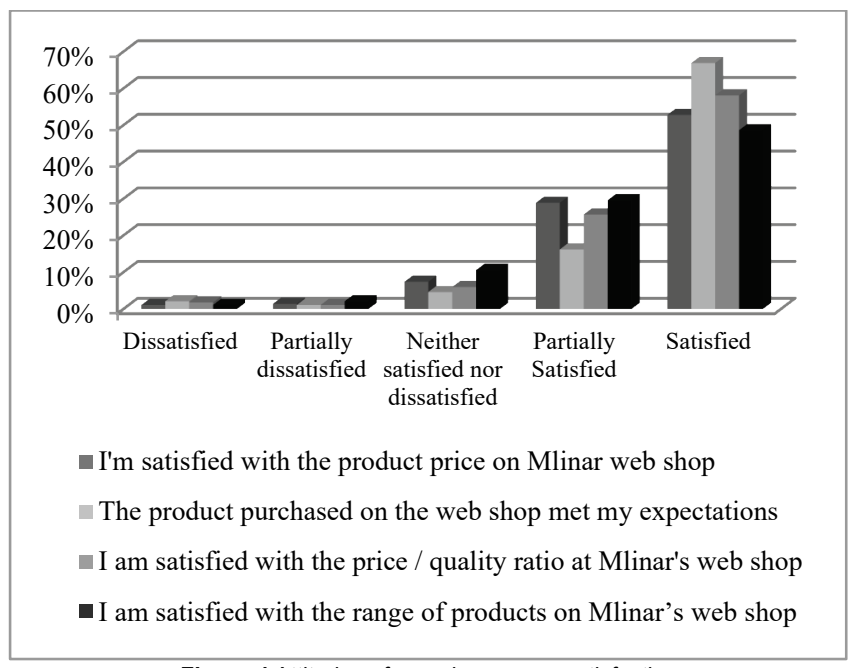

Figure 4 Attitudes of examinees on e-satisfaction

If we look at the attitudes concerning online services, the examinees are completely satisfied with the quality of information on Mlinar's web shop (57,7\%), the quality of the purchase process $(73,9 \%)$, and customer support $(52,5 \%)$. The question about the security of the transaction was to be expected $(25,5 \%$ of examinees were partially or completely satisfied) (Fig. 5).

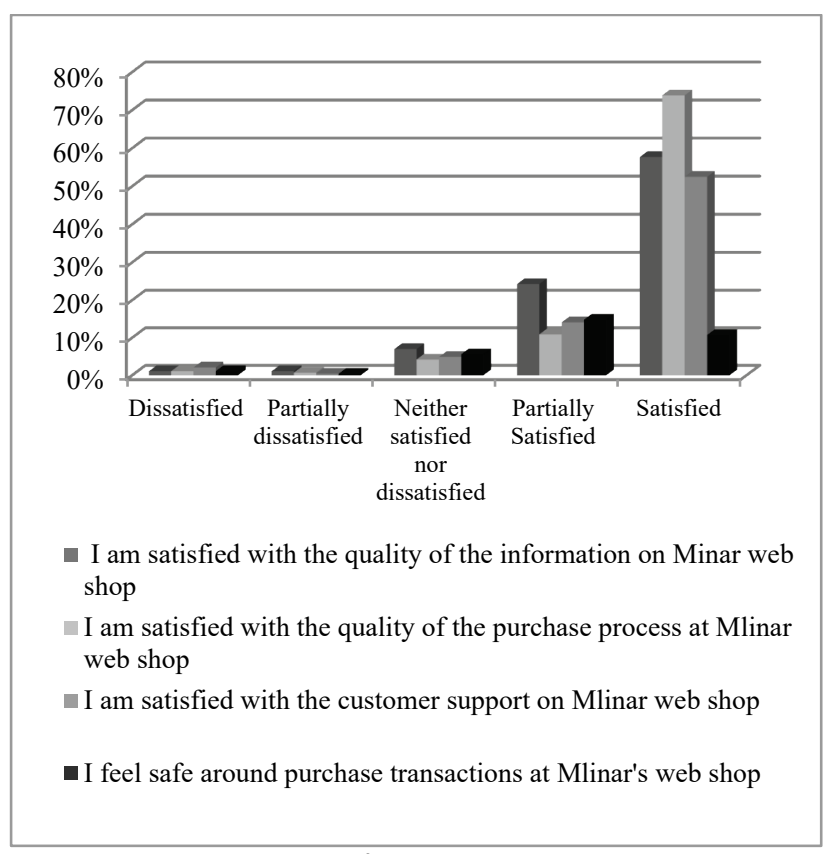

Figure 5 Attitudes of examinees on online services

The following figure shows the attitudes of examinees on e-loyalty, which was observed as a dependent variable in the conceptual model. Namely, $69,7 \%$ of examinees 
completely agree that they will keep following the news on the web shop (sales), 78,2\% of them intend on buying again on the web shop, $84,2 \%$ will say positive things about the web shop, and $86,3 \%$ of examinees would recommend online shopping of torts and/or cakes on Mlinar's web shop to their friends or family (Fig. 6).

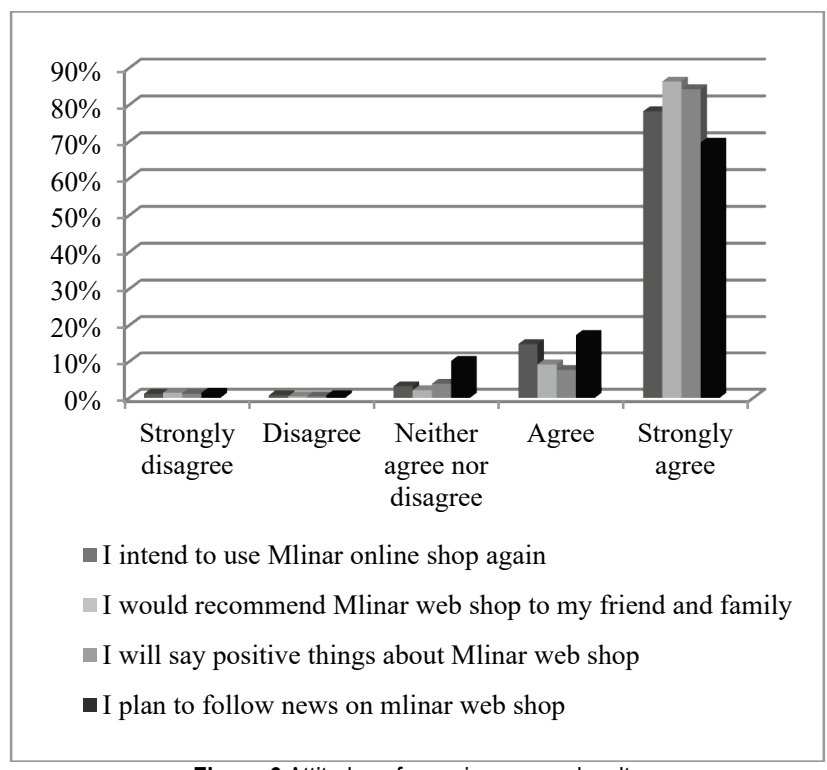

Figure 6 Attitudes of examinees on e-loyalty

Before examining the mutual correlation and performing the regression analysis, it is necessary to examine the Cronbach alpha coefficients of all observed variables. The following is an interpretation of the items used (Cronbach alpha):

- Firm reputation/perceived value $(\alpha=0,741)$

- E-satisfaction $(\alpha=0,870)$

- Online services $(\alpha=0,899)$

- E-loyalty/Intention $(\alpha=0,885)$

The Cronbach alpha coefficient is between 0,741 and 0,899 . All variables have an acceptable and good consistency, which confirms good reliability and stability of the measurement instrument [28] $]^{1}$ (Fig. 7).

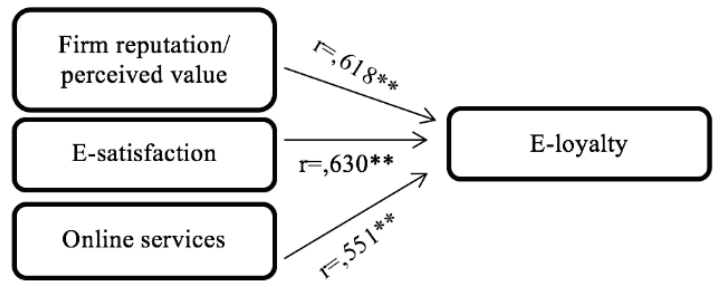

Figure 7 Correlation analysis

**Correlation is significant at the 0,01 level

Regression analysis is used in order to determine the correlation between the observed variables, i.e. the effect of the dependent variables on the independent variable. The influence of individual predictors on consumers' e-loyalty on the web shop was determined by regression (Tab. 2). The model explains the total of $58 \%$ of the variance.

\begin{tabular}{|c|c|c|c|c|}
\hline Predictor variables & ßeta & $t$-value & $\begin{array}{c}\text { Significance } \\
(p)\end{array}$ & $\begin{array}{c}\text { Model } \\
\text { summary }\end{array}$ \\
\hline $\begin{array}{l}\text { Firm reputation/ } \\
\text { perceived value }\end{array}$ & ,377 & 7,245 & 000 & \multirow{3}{*}{$\begin{array}{l}R=0,720 \\
R^{2}=0,581 \\
F=93,883\end{array}$} \\
\hline E-satisfaction & ,364 & 5,746 &, 000 & \\
\hline Online services &, 097 & 1,552 &, 122 & \\
\hline
\end{tabular}

Dependent variable: consumers' e-loyalty on web shop

\section{DISCUSSION OF RESULTS}

Electronic trade for business subjects enables doing business on a global market, offering various benefits for shopping along the way. Even though electronic trade undoubtedly provides advantages, the problems that shoppers face are objectively larger than the problem of traders. The electronic market brings a dose of risk in regards to the classic market because the buyer cannot feel, smell, start, drive, weigh the service/merchandise etc. before shopping for the first time. Therefore, investing into e-loyalty is necessary for the majority of business subjects. The dangers for online shoppers are also the phenomena which cannot be considered fraud, but it can increase the expenses for customers and/or harm them. Research showed that customers appreciate the reputation of a certain web shop because, that way, they can ensure there will be no fraud and they can realize electronic trade so that they extract the maximum benefit and satisfaction from it. Guided by the problems set, this paper had the aim of examining the preferences of customers of specific products. Reasons to buy on Mlinar web shop shows the most significant variables that business subjects can relatively quickly accept and implement into their business. The customers are used to the option of finding information they are interested in at that on the internet. Namely, examinees stated that online shopping enables them to save time and, therefore, business subjects should invest in technology/web shops which simplify purchasing and state this as a competitive advantage. The majority of examinees already shopped online and consider the advantage of e-trade to be quicker and easier shopping, as well as comparing prices. Generally speaking, in order to use the full potential of the advantages and opportunities of e-trade, the observed business subject should develop and accept certain electronic strategies in business. Such an estrategy must be appropriate for the industry, be constantly innovated, and create competitive advantages and new values, which is presented in the model - the variables firm reputation/perceived value, e-satisfaction and online services affect the web shop and create e-loyalty in their users. Research proved that focusing attention on controlling the relations with consumers/clients, and primarily doing so through tracking user satisfaction and investing in technology i.e. additional services on the web shop and

\footnotetext{
$1>.9$ - Excellent, $>.8$ - Good, > .7-Acceptable, > $.6-$

Questionable,_>.5- Poor, and ${ }_{-}<.5$ - Unacceptable
} 
maintaining credibility can actually create a partner relationship. Results showed that, by building a relationship with the consumers within the observed industry, it is possible to create web shop user loyalty which is presented through the intent of future shopping and recommendations to other customers. The trend which is rapidly growing is the growth in the mobile dimension i.e. buying using mobile devices. Taking the aforementioned into account, the recommendation is to expand the model using additional variables which will include mobility i.e. location marketing where every visit to Mlinar will result in sending information to the mobile device. Research confirmed that, in the context of global economy and a large presence of various products and services which are almost universally available, consumers want a product and/or service which are appropriate for them or suit them completely - mass production is now replaced by mass personalization. The next step is to personalize the profiles of users who buy online and track their consumer habits, especially with wide application products such as torts and cakes, which were the object of this research. We can conclude that there is a proportionate relationship between the successfulness of a web shop and user satisfaction because it enables user communication, which is key for keeping them as consumers by increasing the quality of service for consumers and their overall shopping satisfaction, which is defined by the research results. In accordance to research results and the statistical analysis done, we can confirm the hypotheses set i.e. that firm reputation/perceived value, e-satisfaction and online services have a positive impact on e-loyalty.

\section{CONCLUSION}

The authors of the paper wanted to examine which marketing activities can business subjects use to affect the user satisfaction, through tracking the examinees' shopping habits, shopping satisfaction and answering the questions connected to their intents of shopping so far and in the future on the observed and specific business subject. The aim of the research was to see whether there is a connection between the efficiency of a web shop and the influence on consumer behavior. Electronic trade service users have the option of comparing online shops and can, in a short time, change the shop where they wish to buy a product. Because of that, it is of the utmost importance for the business success of a web shop to define a business strategy which will remove the risks and losses in doing business caused by a drop in loyalty of a consumer of e-trade products and services. In order to examine this, the authors performed a research in which they wanted to see what is important for buyers during online shopping i.e. which elements can business subjects implement into their strategy in order to exert influence on consumer behavior. Generally speaking, e-loyalty presents the basic aim to which business subjects, who deal in both online and offline business, strive. Contemporary business demands business subjects to interact directly with the consumers so that, based on the information gathered, they can influence the offer of their products and services, but also marketing activities in general. Unlike the classical offline transaction modes which focused only on sales, today there is a trend of developing and nurturing a relationship with the consumers through the communication process which goes on prior to shopping and after it. The paper sets a conceptual model which attempted to understand in what way do firm reputation/perceived value, e-satisfaction and online services affect e-loyalty. The research was done on examinees who bought a product on the Mlinar web shop. In accordance with the research results, we can conclude that the observed variables can influence the development of e-loyalty towards the subject observed (Mlinar) and its consumers. Even though the observed business subject primarily achieves sale through offline channels, the concept of traditional trade is losing ground to the new, contemporary way of electronic business so it is, therefore, necessary to build a clear strategy of acting in the electronic market. The limitations of the paper are the fact that only one business subject selling specific products was observed. This definitely limited research results, given that the offer of such products is limited. Also, in a logistical sense, the buyer must physically get the product, meaning that in the post-shopping activities there is also the experience they had in the store. A limitation can also be the fact that the observed business subject only recently started using the web shop as a sales and distribution channel for their products and is insufficiently familiarized with their consumers in order to be able to get to know their habits, given the fact that there isn't a large number of consumers who made several purchases. Also, this paper observed a business subject who introduced a relative innovation in the sale of the aforementioned products by way of internet, given that there isn't a similar model (when the observed product group is concerned). This is precisely the recommendation of the authors for further research - to expand it to other industries dealing in the similar model where the product needs to be ordered online but taken by the customer themselves. Given that the authors only examined those people who bought the product online, the aim of the authors is also to survey the customers who do not buy their products online and those who have the intent to do so but give up at a certain point. That way, there could be a more detailed insight into the pre-purchase activities and reasons why some customers give up during the act of shopping. The result is in the fact that tracking consumer habits is necessary in order for business subjects to be able to define key variables which can serve as specific measures to advance web shops, with the aim of influencing consumer behavior and their travel before and after shopping.

\section{REFERENCES}

[1] Kardes, F., Cronley, M., \& Cline, T. (2011). Consumer Behavior. Mason, OH, South-Western Cengage.

[2] Kuester, S. (2012). MKT 301: Strategic Marketing \& Marketing in Specific Industry Contexts, University of Mannheim.

[3] Kassarjian, H. H. (1971). Personality and consumer behavior: A review. Journal of marketing Research, 8(4), 409-418. https://doi.org/10.2307/3150229 
[4] Berners-Lee, T. \& Fischetti, M. (2001). Weaving the Web: The original design and ultimate destiny of the World Wide Web by its inventor. DIANE Publishing Company.

[5] Hernández, B., Jiménez, J., \& Martín, M. J. (2010). Customer behavior in electronic commerce: The moderating effect of epurchasing experience. Journal of business research, 63(9-10), 964-971. https://doi.org/10.1016/j.jbusres.2009.01.019

[6] Mohammed, R. A., Fisher, R. J., Jaworshi, B. J. \& Cahill, A. M. (2002). Internet Marketing-Building Advantage in a Network Economy. International edition, McGraw-Hill, Irwin Marketspace.

[7] Kwan, I. S., Fong, J., \& Wong, H. K. (2005). An e-customer behavior model with online analytical mining for internet marketing planning. Decision Support Systems, 41(1), pp. 189204. https://doi.org/10.1016/j.dss.2004.11.012

[8] Aldridge, A., White, M., \& Forcht, K. (1997). Security considerations of doing business via the Internet: cautions to be considered, Internet Research, 7 (1), 9-15. https://doi.org/10.1108/10662249710159809

[9] Barnard, L. \& Solms, R. (1998). The evaluation and certification of information security against BS 7799 . Information Management \& Computer Security, 6 (2), 72-77. https://doi.org/10.1108/09685229810209397

[10] Feindt, S., Jeffcoate, J., \& Chappell, C. (2002). Identifying success factors for rapid growth in SME e-commerce. Small business economics, 19(1), 51-62. https://doi.org/10.1023/A:1016165825476

[11] Hoffman, D. L., Novak, T. P., \& Peralta, M. (1999). Building consumer trust online. Communications of the ACM, 42(4), 8085. https://doi.org/10.1145/299157.299175

[12] Ngai, E. W. T. \& Wat, F. K. T. (2002). A literature review and classification of electronic commerce research. Information and Management, 39, 415-429. https://doi.org/10.1016/S0378-7206(01)00107-0

[13] Monsuwé, T. P., Dellaert, B. G., \& De Ruyter, K. (2004). What drives consumers to shop online? A literature review. International journal of service industry management. 15(1), 102-121. https://doi.org/10.1108/09564230410523358

[14] Davis, F. D. (1989). Perceived usefulness, perceived ease of use, and user acceptance of information technology, MIS Quarterly, 13(3), 319-40. https://doi.org/10.2307/249008

[15] Davis, F. D. (1993). User acceptance of information technology: system characteristics, user perceptions and behavioral impacts, International Journal of Man-Machine Studies, 38(3), 475-87. https://doi.org/10.1006/imms.1993.1022

[16] Sultan, M. U. \& Uddin, N. (2011). Consumers' attitude towards online shopping. MBA Thesis. Business Administration. Uppsala University. Visby.

[17] Kavitha, T. (2017). Consumer buying behavior of online shopping-A study. International Journal of Research in Management \& Business Studies, 4(3), 38-41.

[18] Nazir, S., Tayyab, A., Sajid, A., Rashid, H., \& Javed, I. (2012). How online shopping is affecting consumers buying behavior in Pakistan? International Journal of Computer Science Issues, 9(3), pp.486-495.

[19] Kotler, P. \& Armstrong, G. (2010), Principles of Marketing, $\left(13^{\text {th }}\right.$ edition). New Jersey: Pearson Education.

[20] Lin, C. C. (2003). A critical appraisal of customer satisfaction and e commerce. Managerial Auditing Journal, 18(3), 202212. https://doi.org/10.1108/02686900310469952

[21] Gommans, M., Krishman, K. S., \& Scheffold, K. B. (2001). From brand loyalty to e-loyalty: A conceptual framework. Journal of Economic \& Social Research, 3(1).
[22] Bellman, S., Lohse, G., \& Johnson, E. (1999). Predictors of online buying behavior. Communications of the ACM, 42(12), 32-38. https://doi.org/10.1145/322796.322805

[23] Amit, K. S. \& Sailo, M. (2013). Consumer Behavior in Online Shopping: A Study of Aizawl. International Journal of Business \& Management Research, 45-39.

[24] Baba M.M. \& Siddiqi M. A. (2016). Attitude of Consumers towards Online Shopping. Chapter 11, Marketing in Emerging Economies, Manakin Publishers.

[25] Rahman, M. A., Islam, M. A., Esha, B. H. \& Sultana, N., Chakravorty, S. (2018). Consumer buying behavior towards online shopping: An empirical study on Dhaka city, Bangladesh. Cogent Business \& Management, 5(1), 1514940. https://doi.org/10.1080/23311975.2018.1514940

[26] Farah, G. A., Ahmad, M., Muqarrab, H., Turi, J. A., \& Bashir, S. (2018). Online Shopping Behaviors among University Students: Case Study of Must University. Advances in social Sciences Research Journal, 5(4), 228-242. https://doi.org/10.14738/assrj.54.4429

[27] Cater, T. \& Cater, B. (2010). Product and relationship quality influence on customer commitment and loyalty in B2B manufacturing relationships. Industrial Marketing Management, 39(8), 1321-1333. https://doi.org/10.1016/j.indmarman.2010.02.006

[28] George, D. \& Mallery, P. (2003) SPSS for Windows step by step: A simple guide and reference. 11.0 update $\left(4^{\text {th }}\right.$ ed.), Boston: Allyn \& Bacon.

\section{Authors' contacts:}

Helena Štimac, $\mathrm{PhD}$

Faculty of Economics Osijek,

Gajev trg 7, 31000 Osijek, Croatia

0038531224400, helena.stimac@efos.hr

Ivan Kelić, PhD

(Corresponding author)

Faculty of Economics Osijek,

Gajev $\operatorname{trg} 7,31000$ Osijek, Croatia

0038531224400, ivan.kelic@efos.hr

Karla Bilandžić, M.A.

Faculty of Economics Osijek,

Gajev trg 7, 31000 Osijek, Croatia

karla.bilandzic@efos.hr 